\title{
Research on Management Accounting of Fixed Assets at Vinacomin, Vietnam
}

\author{
Thi Hue Dang, Thi Dieu Thu Nguyen \\ University of Transport Technology, Vietnam \\ Thi Thu Huyen Vu \\ Thuongmai University, Vietnam \\ Nguyen Manh Dang \\ Thai Binh University, Vietnam \\ Manh Dung Tran \\ National Economics University, Vietnam \\ Duc Tuyen Luu \\ Ministry of Finance, Vietnam
}

\begin{abstract}
The research was conducted to find out about the current situation of management accounting for fixed assets at enterprises of Vietnam National Coal and Mineral Industries Holding Corporation (Vinacomin), Vietnam. Data was collected through interviews with directors, chief accountants, fixed-asset accountants, heads of other departments in the surveyed enterprises, auditors, experts in accounting and auditing field. Analytical procedures are employed in this research. The results indicate that the management and use of fixed assets in enterprises of Vinacomin are still inefficient; applying the improper depreciation methods for each type of fixed assets; most enterprises have not yet developed and analyzed the system of indicators to assess investment situation, technical status and efficiency of using fixed assets.
\end{abstract}

Keywords: Management accounting, fixed assets, efficient use, Vinacomin.

DOI: $10.7176 / \mathrm{JRDM} / 61-04$

Publication date: November $30^{\text {th }} 2019$

\section{Introduction}

With the development of 4.0 technology revolution, Vinacomin enterprises continue to equip and renew fixed assets to have access to modern technology processes, contributing to the increase in labor productivity, promoting the sustainable prosperities of businesses. Fixed assets in enterprises of Vinacomin account for a relatively large proportion of the total value of the enterprise's assets, therefore, management accounting of fixed asset management is considered as an important part of the accounting system of the business. Management accounting for fixed assets is aimed to collect, process, analyze and provide information on how to invest, manage and use fixed assets to have the highest efficiency, a matter to be discussed, exchanged and also a problem facing businesses of Vinacomin for the time being.

Important and decisive information that governs the investment in replacement as well as the use of fixed assets is the one provided by the fixed asset management accounting. However, at enterprises of Vinacomin currently, the management accounting of fixed assets has not been given adequate attention by the administrators; when developing investment plans, the information collected is not clear and complete. The provision of accounting information on fixed assets from the perspective of management accounting affects the process of planning, controlling and evaluating the implementation of plans within enterprises. Therefore, it is necessary to study and improve management accounting of fixed assets in Vinacomin enterprises in the current period.

\section{Theoretical framework of management accounting of fixed assets}

Management accounting for fixed assets is a part of management accounting, so it plays an important role in the decisions of administrators at all levels in the enterprises. Being aware of the managers' needs for information to make decisions related to the process of investment, management and use of fixed assets, namely: Deciding on appropriate and timely investment in fixed assets to meet business expectations; formulating reasonable capital recovery policies, minimizing risks; managing effectively fixed assets during the use; deciding to replace or reinvest in fixed assets according to the enterprise's strategy; evaluating the effectiveness of using fixed assets. Therefore, fixed asset management accounting needs to collect, process, analyze and provide information for making decisions regarding investment, management and use of fixed assets. 
a, Management accounting with collection, processing, analysis and provision of information for making decisions on fixed assets investment

Decisions related to fixed assets are usually long-term ones, associated with the period of investment, use, liquidation and sale of fixed assets. In the investment phase, enterprises must build a list of fixed assets to be invested based on its operating characteristics as well as the current use of fixed assets. On that basis, businesses need to consider the proper investment methods to meet the needs of the businesses, financial capacity and to achieve the highest economic efficiency. However, investment decisions are a complex, long-term, risky type of decision, and it is difficult to change once implemented. Therefore, the information provided for these decisions comes from various channels including financial and non-financial information, but only the financial information related to the project is within the scope of accounting. The information collected to provide for the management's decision making regarding fixed asset investments includes performance information and future information. The performance information is collected mainly through the accounting system. On this basis, presenting information about fixed assets based on the reports on the use of fixed assets to assess the existing business capacity of the enterprise. In terms of future information, managers often base on the existing situation, current situation and level of use of fixed assets, operational objectives and financial capacity of enterprises to determine the need for assets. Based on the demand for fixed assets of each department, the enterprise determines the number of each type of fixed assets needed to serve the business and production activities of the enterprise, thereby planning to build the pre-feasible strategy. When formulating plans for investment in fixed assets, the accounting department must work with other departments of the enterprise, such as the planning department, the technical department, the division of construction investment, the sales department,... in order to collect information on prices, technical features, origin of fixed assets likely to be invested, benefits that fixed assets bring in the future, forms of payment when investing to estimate basic financial information related to investment decisions:

- Estimated investment capital related to the project, includes: Initial investment capital for construction and procurement of machinery and equipment; additional working capital during project operation; capital for upgrading and repairing fixed assets of the project; sources of investment capital mobilization; disbursement time; payback time...

- Estimated future cash flow earned from project implementation, including profits and depreciation of fixed assets of the project.

After obtaining information related to fixed asset investment, the accountants will process the information collected by the processing techniques. The use of technical equipment in information processing is modernized including computer systems and information processing software such as accounting software, internal management software, etc. to help process information more quickly and more accurately.

In order to provide information useful for managers to make decisions regarding fixed asset investments, accountants should analyze the information to select the appropriate information. Based on the expected revenue and expenditure flow of the investment plan, the enterprise will estimate the investment capital budget for the project. The estimate of capital budget related to investment in fixed assets is the preparation of tables reflecting the enterprise's existing capital amount and proposed plan of raising capital. If it is loan capital, where are the sources? How much is the interest rate? What is the term for loans?... After estimating the capital budget, businesses use technical methods to analyze information. Depending on the certain case, businesses can choose appropriate methods to analyze and make decisions such as: Net present value method (NPV - Net Present value), internal profitability method (IRR - Internal Rate of Return), method of profitability index (Profitability Index (PI), method of payback period (PP).

- In case the enterprise is interested in the economic efficiency of the investment plan, the scale of the project's capital and the added value increased by the investment capital,... it is necessary to select the investment plan suitable to the goal of profit maximization of the business. The enterprise then can use the NPV method and chooses the investment option with positive NPV if the options are independent of each other. When the plan is mutually exclusive, the enterprise chooses the option with the largest NPV.

- In case the investment plan is implemented from the loan capital, then the capital costs that the enterprise has to pay and the profitability of the project are two factors that the business needs to consider when determining between raising capital and the effective use of capital of the plan. In this situation, the enterprise needs to choose the IRR method. This method assesses the project's ability to offset the cost of capital compared to its risks. If the project has an IRR $>\mathrm{r}$ (capital cost), that is, a profit after subtracting the remaining investment cost is a profit, it accumulates to increase the assets of the business. Therefore, choosing projects with an IRR greater than the cost of capital will increase the assets of the business.

- In case the project has many risk factors (environment with many fluctuations), investment plan with small and medium scale or for enterprises with quick capital recovery strategy, businesses should choose periodic payback (PP) for making investment decisions. According to this method, if the payback period is shortened, the risks are less or in other words, this method focuses on short-term benefits over long-term benefits. 
However, the payback method does not take into account the time value of the currency and does not consider the profitability of the project, so projects with a short payback period are not necessarily more beneficial. In other projects, if this method is used independently to select a project, the business may encounter mistakes when making decisions. Therefore, businesses need to combine the above methods to make decisions to choose the most optimal plan.

Based on the analysis of information, the accountants of fixed asset management provide information to the managers to make decisions about fixed asset investment through reports such as the investment cost estimate report, information analysis reports suitable for decision-making.

b, Management accounting with the collection, processing, analysis and provision of information for management and use of fixed assets

When putting fixed assets into use, the objective of the enterprise is to manage fixed assets scientifically and reasonably; to use fixed assets effectively; quick return of investment capital; minimizing risks... Therefore, accountants of fixed asset management must provide information to managers to make decisions about the management and use of fixed assets in the most effective way.

\section{* Management of fixed assets}

During the usage period, the goal of the business is that fixed assets must be scientifically managed and used effectively. In order to achieve these goals, fixed assets must be strictly managed both in types and in value. The management of fixed assets is performed on the system of detailed accounting of fixed assets at the place of use and at the Accounting Department. At the place of use, it is necessary to manage and monitor the types of fixed assets through establishing fixed asset codes, recording fixed assets at the place of use. At the end of the period, the using department reports on the use of fixed assets and the technical status of the fixed assets. At the Accounting Department, it is necessary to keep track of fixed assets in terms of value through the creation of fixed asset cards and fixed asset books. All fixed assets in the enterprise must have a separate document file. Because fixed assets exist in a long term in the enterprise, they must be classified, listed, numbered and have their own cards, monitored in detail by each inscribed subject and reflected in the Fixed Asset Book. Periodically, enterprises conduct inventory checks of fixed assets with the participation of representatives of the departments: accounting, using units and technicians. All cases of redundancy or shortage of fixed assets must be recorded in a minute, identifying the causes and taking measures to handle promptly.

In order to find out about the situation of management and use of fixed assets, the management accountants should collect information from the using department, technical department, and fixed asset repair department through the documents about repairing fixed assets, the book of expenses for repairing fixed assets, the book for monitoring fixed assets at the place of use, etc. In addition, the management accountant also collects information through internal regulations regarding the enterprise's division of assignment and responsibilities of individuals and divisions for monitoring and operating machinery, transport means and other fixed assets.

* Management accounting with the selection of fixed asset depreciation policies

When putting fixed assets into use, the first concern of the enterprise is to select the appropriate depreciation policy for each type of fixed assets, in order to ensure the compatibility of costs that the businesses spent with the benefits obtained in each accounting period, at the same time meeting the business objectives. The depreciation policy is the selection of the cost allocation technique of fixed assets throughout the life of the fixed assets. The choice of allocation technique has a direct impact on the return on investment. There are two allocation techniques including straight line depreciation and accelerated depreciation. The depreciation policy is built first based on the management objectives of the enterprise. If the business is concerned about the stability of costs, revenues and business profits between periods, then the enterprise should choose the straight-line depreciation method. If the enterprise needs to recover capital quickly and avoid risks when investing, it should use the accelerated depreciation method. In addition, enterprises can choose the method of depreciation based on the nature of production and business activities, characteristics of each type of fixed assets, and conditions for using fixed assets. Thus, the depreciation policy will determine the selection of the depreciation method of the business. Choosing the appropriate depreciation method is an important measure to preserve fixed capital and is also an important basis for determining the payback period for investing in fixed assets from long-term funding sources. Methods of depreciation of fixed assets that enterprises can choose to suit each type of fixed assets such as straight-line depreciation method, method of depreciation according to descending balance and the depreciation method according to the output. However, the depreciation method must be applied consistently, unless there is a change in the way the asset is used.

Therefore, in order to obtain information to make decisions on the application of the method of depreciation of fixed assets, management accounting is based on related vouchers to determine the original cost of fixed assets; documents regulating the content and conditions of the depreciation methods, the provisions of the Tax Law on depreciation expenses; conditions of using fixed assets, quickly or slowly worn and torn characteristics of fixed assets, estimated use time... That is also the basis for preparing the spreadsheet and depreciation of fixed assets. The fixed asset depreciation data from this table will serve as a basis for estimating profits and corporate 
income tax liability for the accounting period. Consequently, according to the goal of the management, the information needs to meet requirements for making decisions on selecting an appropriate depreciation method.

\section{* Evaluating the efficiency of fixed assets investment and usage}

The goal of an enterprise in using fixed assets is to use up the capacity of machinery and equipment; for offices, warehouses and workshops, all of the ground space must be exploited and other fixed assets must be fully used. However, businesses still have to ensure that fixed assets are in their best working situation throughout the estimated use life. Therefore, enterprises must have regular and periodic maintenance and repair plans for fixed assets, ensuring the maintenance and prolonging the life of fixed assets.

Besides selecting the appropriate depreciation policy, checking and evaluating investment efficiency, effectiveness and technical status of fixed assets are also an important part of corporate management.

Assessing the effectiveness of fixed asset investment: Information about fixed assets provided by internal departments will be the basis for summarizing, analyzing and making a new fixed asset investment plan or make plans and cost estimates for repairing, renovating and upgrading fixed assets in accordance with the financial capacity, ensuring the rationality in production and business activities of the enterprise. This is the predictive information for future investment in fixed assets procurement and prospects for use of fixed assets. The accountants should make a table comparing expenses of depreciation, repair, maintenance and upgrading of fixed assets between this period and the previous period, between reality and the plan to control expenses. In addition, in order to have useful information on fixed asset investment, the fixed asset management accountants need to build a system of indicators reflecting the investment and equipment situation in fixed assets in the enterprise. The figures of these criteria are created by the fixed asset management accountants from related accounting books and financial statements of the enterprises. Then, the accountants compare the indicators of the investment situation, equipping fixed assets of this year with previous years to see the level of investment of the business. Consequently, managers can make appropriate future decisions on the situation of fixed asset investment.

Assessment of the technical status of fixed assets: In addition to grasping the situation of using fixed assets of departments, enterprises must conduct the technical status assessment of each fixed asset in the enterprise in order to determine the correct level of fixed assets whether it is new or old, how new or old it is; whether it is necessary to repair or replace with new assets or not... To achieve this, accountants need to build a system of indicators that reflect the technical status and use of fixed assets in the enterprise. Data reflecting these indicators are collected by the management accountants from financial statements provided by financial accountants and documents provided by the technical department. By assessing the technical status of fixed assets, the accounting department of fixed asset management as well as the technical department will advise the management on the plans for repairing and maintaining fixed assets regularly, periodically, and at the same time to take measures to manage and use fixed assets appropriately.

Evaluating the efficiency of using fixed assets: Evaluating the efficiency of fixed asset usage will help managers assess whether the investment and use of fixed assets are reasonable or not, then have measures to manage both in types as well as the value effectively, meeting the requirements of business production. Based on the characteristics of production and business activities, management and organizational characteristics, internal corporate governance requirements, the accountants formulate criteria to evaluate the efficiency of the fixed asset usage in enterprises. After a business period, accountants need to evaluate the efficiency of using fixed assets of each division, each unit as well as the whole enterprise. This is the basis for comparing the plan with the implementation, between the fact in this period and the previous period, thereby proposing measures and plans to improve production organization and complete the structure of fixed assets in order to exploit and use assets appropriately. Is the evaluation of the effectiveness of fixed assets usage in accounting periods considered as one of the important bases for managers to make decisions on whether to continue investing in these fixed assets or not? How to manage and use fixed assets to have the highest efficiency?

Information on the situation of investment, use and efficiency of fixed assets is provided by management accounting in the form of management accounting reports such as: Reports on increase or decrease of fixed assets; Reports on depreciation of fixed assets; Reports on the technical state of fixed assets, Reports on the efficiency of use of fixed assets... These reports are made for the purpose of providing information about fixed assets to the internal enterprise. Therefore, it is not mandatory but dependent on the request of information provided by the enterprise managers.

In conclusion, the information provided by the accounting management on fixed assets helps businesses to understand the current situation and the efficiency of using fixed assets in each department to have a direction in the investment process, in management and use of fixed assets in upcoming periods.

\section{Research Methodology}

This study focuses on the research of fixed assets management accounting with the collection, processing, analysis and provision of information for making decisions on investment, management and use of fixed assets at 
76 enterprises of Vinacomin, from 2016 to 2018, in which, qualitative research methods are used to investigate the current situation of accounting management of fixed assets at enterprises of Vinacomin through the combination of data collection methods:

Secondary data: We conducted statistical studies of the research related to the article; conducting observations, research of documents on fixed assets, accounting of fixed assets management and other documents in the surveyed units; collecting and analyzing research results of domestic and foreign scientists related to the article, thereby determining the content of fixed asset management accounting.

Primary data: Collecting documents through methods such as sending survey questionnaires, direct interviews.

To implement the method, the research team designed survey questionnaires, including closed-ended and open-ended questions, to be sent to: Managers and accountants, employees of a number of other divisions in the businesses of Vinacomin. In addition, the author group also interviewed experts directly with in-depth knowledge to form the theoretical system of fixed asset management accounting. In practical terms, the author's group consults with the fixed asset accountant, the chief accountant or the accounting department, the manager of the fixed assets department, the director or the deputy director, heads of other departments of enterprises of Vinacomin, auditors who have audited at a number of enterprises of the Group, experts of the Ministry of Finance to further study the research topic. The interview content revolves around the actual situation, the advantages and limitations of the current situation of accounting and management of fixed assets of Vinacomin enterprises.

\section{Results and Discussions}

4.1. Collecting, processing, analyzing and providing information as a basis for making decisions on fixed asset investment in enterprises of Vinacomin

\section{* Collecting fixed asset information}

According to the interview results, Vinacomin enterprises collect information on fixed assets including performance information and future information. Implementation information is one related to purchase, equipment, depreciation, repair, transfer, liquidation, sale of fixed assets. Future information includes information on revenue estimates, expenditure; budget estimates of investment capital for fixed assets; market prices of fixed assets; information on properties, utilities and specifications of fixed assets preparing for investment. Enterprises of Vinacomin said that the source of information collected on fixed assets is mainly the data from accounting records based on accounting vouchers, accounting books provided by the internal accounting department. The main basis for estimating investment costs is based on information collected on the use of fixed assets of the same type... In addition, information is collected from other departments such as pricing information from the planning department; information on the estimated cash flow in, cash flow out and budget estimates of investment capital collected from the construction investment department; information on properties, utilities and specifications of fixed assets was collected from the technical department. The majority of businesses $(89.47 \%)$ responded that before the managers decide to invest, enterprises need to identify what the real needs for fixed assets of an enterprise are? The determination of fixed asset investment is made by the construction investment department by submitting to the directors for approval. After that, the technical department will consider the technical factors of each type of fixed assets that need new investment, the planning department will study equipment suppliers, prices,... to submit the purchase plan of specific fixed assets serving project implementation such as the quantity, type, origin... to help the directors make the final decision.

The majority of enterprises (86.84\%) said that before making a decision to invest in purchase, business managers based on information provided by departments and agencies such as the construction investment department, the planning department, the accounting department to make a decision, but there is still little close contact and smooth coordination between these departments and the information provided has not met the requirements of business managers.

\section{* Handling fixed asset information}

Surveyed businesses said that participants in the process of processing information related to fixed asset investment include: fixed asset accountants, chief accountant (or deputy chief accountant), chief (or deputy) other business departments in the enterprise. Most managers at enterprises of Vinacomin are interested in accounting management for fixed asset, but the level of interest is still limited.

Regarding fixed asset information processing facilities: $100 \%$ of accounting staff are equipped with one computer each and $61.84 \%$ of enterprises surveyed apply accounting software to assist in the processing of accounting information on fixed assets, the remaining enterprises only process data on excel; No enterprise has applied fixed asset management software for the whole enterprise, so the processing of accounting information for fixed assets has not been timely provided to managers.

Performance information about fixed assets is handled by the fixed asset management accounting through the system of vouchers, detailed accounting accounts and detailed accounting books of fixed assets, detailed 
information about expenditures, the cost of investment in fixed asset, depreciation expense, fixed asset repair expense,... along with future information such as cash flow in, cash flow out of the project,... will be summing up to make estimates for investment in fixed assets.

\section{* Analysing and providing information on fixed assets}

The subjects of fixed asset information analysis are the people who directly use techniques to analyze information serving the decisions to invest in fixed assets. According to the survey results, $100 \%$ was made by the manager or deputy manager of accounting department, $23.68 \%$ by the fixed asset accounting department and $27.63 \%$ by the cost estimation department specifically.

Regarding the formation of an investment plan, $67.1 \%$ of enterprises did not plan to invest in purchase of fixed assets annually. Before deciding to invest in fixed assets, only $59.21 \%$ of enterprises conducted research to determine the needs for fixed assets and investment opportunities. Then, based on the information provided by the accounting department about the amount of owner's equity that can be mobilized, the amount of loan capital and the information provided by other departments, the planning division combines with other departments in order to implement a fixed asset investment plan, and a large amount of capital is usually required. In the current economic conditions, the financial capacity of Vinacomin enterprises is limited, therefore, $100 \%$ of businesses invest in purchasing fixed assets mainly with loans.

At the surveyed units, the analysis of information to evaluate the effectiveness of the project is limited, the ratio of using the net present value method - NPV is $31.58 \%$, the rate of internal return method - IRR is $27.63 \%$. Other methods such as payback period - PP (11.84\%) and profitability index - PI (5.26\%) methods were hardly used for information analysis. In some enterprises of Vinacomin, the information analysis method used to prepare the investment plan mainly consists of NPV and IRR. In particular, the NPV and IRR calculation formulas are pre-programmed in Excel spreadsheets with the discount rate used to calculate the present value of cash flows, mainly the cost of using commercial loans of the project. However, in each specific case businesses will use NPV or IRR method or a combination of both methods.

\subsection{Collecting, processing, analyzing and providing information for management and use of fixed assets at enterprises of Vinacomin \\ * Management of fixed assets}

Fixed assets constitute a large part of the total assets, affecting the operational efficiency of Vinacomin enterprises. Through the survey, we found that the management of fixed assets in these enterprises has the following characteristics:

In the departments using fixed assets: $100 \%$ of Vinacomin enterprises continue to use many fullydepreciated fixed assets such as cars, generators, office buildings, excavators, drilling machines. This fact forces enterprises to spend a large repair costs to continue using those assets or in the process of using assets, technical problems may occur due to the expiry of assets. Many businesses have not yet labeled fixed assets, which can cause certain difficulties for the monitoring, inventory checks and management of fixed assets within businesses as well as each department using fixed assets. According to the results of interviews with technical staff, most Vinacomin enterprises do not have a clear division of responsibilities for the management of fixed assets at the using departments, and there is no plan for periodic inspection and maintenance of fixed assets. Therefore, when the fixed assets are damaged, the departments using fixed assets require the technical department to repair.

At the Accounting Department: Only $22.37 \%$ of enterprises used fixed asset cards for each asset, the rest only reflected on the Fixed asset detail book. The accounting department is responsible for monitoring and reflecting the changes in each type of fixed assets according to the historical cost, accumulated depreciation and residual values. The technical department and the planning division are responsible for monitoring and managing fixed assets in types, quantity, technical status, ability to operate fixed assets, and developing standards and regulations for management and use of fixed assets. Periodically, based on the detailed book of fixed assets, the accounting department is responsible for constructing accounting reports to provide information on the current situation and usage situation of each type of fixed assets with the purpose of managing and making decisions related to fixed assets.

\section{* Selecting the fixed asset depreciation policy}

Vinacomin enterprises mainly select the depreciation policy in accordance with the regulations of the tax authorities. $81.58 \%$ of enterprises only use the straight-line depreciation method to calculate depreciation for all types of fixed assets. These enterprises do not apply the method of accelerated depreciation to avoid large changes in costs, incomes and profits between periods, and do not want to adjust the figures when calculating corporate income tax. Only $18.42 \%$ of enterprises apply both straight-line depreciation method and accelerated depreciation method, depending on the characteristics of each fixed asset such as Nui Beo Coal JSC, Ha Tu Coal JSC, Vang Danh Coal JSC... In particular, these businesses have applied the method of accelerated depreciation method for the machinery and equipment used in coal mining pits such as troughs, hydraulic pumps, compressors... The chief auditors at these enterprises said that the reason why they applied the accelerated 
depreciation method is that the assets are quickly outdated in technology so the enterprises want to quickly recover the investment capital to re-invest in new and more modern fixed assets to have higher economic efficiency. In addition, those assets are greatly influenced by factors of the natural environment, which leads to quick tangible depreciation, so businesses need to calculate accelerated depreciation to recover capital before the fixed assets are damaged. Consequently, the basis for choosing the depreciation policy of Vinacomin enterprises is the goal of the administrator.

\section{* Assessing the efficiency of investment and using fixed assets}

Most surveyed businesses only assess the use of fixed assets technically to see if there are failures of parts and components; levels of damage; which parts need to be replaced and repaired..., and they do not use indicators to assess the technical status of fixed assets. Few businesses analyze and evaluate the efficiency of using fixed assets, $15.79 \%$ of enterprises used the criteria Production capacity of fixed assets, $11.84 \%$ used the criteria Profitability of fixed assets and $13.16 \%$ used the criteria Return on assets (ROA). These ratios increase gradually, showing that the trend of using fixed assets is better and vice versa. Based on that, providing information to managers about whether the investment and usage of existing fixed assets at the enterprise is effective or not? This is a useful information channel to help managers make decisions on investing in fixed assets similar to those in use or not?

\subsection{Research findings}

Based on the survey data on management accounting of fixed assets in enterprises of Vinacomin in 2016-2018, we found that:

Firstly, enterprises of Vinacomin have not yet determined the content of information collected by the departments and the information connected between departments. There has been no close contact and coordination among departments in providing information to formulate investment plans for fixed assets. Therefore, the management accounting information of fixed assets is not timely, adequate, and does not meet the requirements of the managers in making decisions on investment in fixed assets.

Secondly, many businesses have not yet assigned a number for each fixed asset, which will cause certain difficulties for the tracking, inventory checks and management of fixed assets throughout the enterprise as well as each department using fixed assets.

Thirdly: The surveyed businesses use a large number of fixed assets that have been fully depreciated, which can reduce investment costs for businesses but increase operating costs, while bringing many risks in the process of using these fixed assets.

- Fourthly: The application of the straight-line depreciation method for all types of fixed assets at most of Vinacomin enterprises is currently unreasonable in the case of the different levels of operation of the assets at different times. Moreover, this method of depreciation slows down the process of recovering invested capital of enterprises.

- Fifthly: Reports on fixed asset management accounting are not sufficient and timely to ensure providing information for the managers in making decisions to choose the optimal plan.

- Sixthly: Most enterprises of Vinacomin do not build and analyze the system of criteria to evaluate the investment situation, technical status and efficiency of using fixed assets, but management accounting only provides detailed information on equipment situation and the changes of fixed assets. Therefore, the information provided on the efficiency of investment and use of fixed assets in each department is still inadequate, leading to the fact that management accounting of fixed asset does not fully promote its role in business management.

\section{Recommendations}

From the review of previous studies and the survey of management accounting practice of fixed assets in enterprises of Vinacomin, we propose following solutions to complete management accounting of fixed asset in these enterprises

\subsection{Improving the process of collecting, processing, analyzing and providing information for decision making} on fixed assets investment

* Improving the collection of information for making decisions on fixed asset investment. To improve the collection of information for decision making on fixed assets investment, first of all, what are the information systems that Vinacomin managers need to provide? At the same time, clearly defining the relationship between the rights and responsibilities of the fixed asset management accounting department; the regulations on coordination of work between the accounting department of fixed asset management and other related departments as below: 
Table 1: Relationship between accounting department and other related departments in collecting information about fixed assets

Other departments Accounting information collected from other departments

Planning Department

Market Department

Labor Department

Technical Department

Production and consumption Department

Estimate Department Information on production and business plans to make investments in purchase of fixed assets during the year, development strategies for the preparation of estimates to provide methods, types and time of investment in fixed assets in accordance with financial capacity.

Information on prices, market share of suppliers, information on prices of inputs for the estimation of fixed assets investment.

Information on labor norms, wage unit prices, quantities and labor structure for the preparation of relevant estimates.

Information about features, utilities, characteristics, quality of fixed assets prepared for investment.

Information about the volume of products expected to be consumed annually for the preparation of investment estimates of fixed assets.

Information about the cash flow in, cash flow out of investment projects, economic efficiency, social efficiency if the project is implemented.

After collecting information provided by the relevant departments, the general fixed asset management accounting will prepare a management accounting report to provide information for managers to make decisions on fixed asset investment.

* Complete the processing and analysis of information to make decisions on investment in fixed assets.

If an enterprise establishes a fixed asset investment project, after collecting sufficient information from other departments, divisions within the enterprise, the project department or the management accounting department will be responsible for planning investment projects. The preparation of an investment project must be based on an analysis of future forecasting factors from the use of fixed assets in a realistic way and will be a reference basis for the efficiency of use made in the following accounting periods. Next, enterprises need to know how to coordinate and flexibly apply the methods of analyzing, evaluating and selecting investment projects in each specific case as follows:

- For short-term projects with little capital investment, the investor's goal is high profits and low risks, the appropriate method is the payback period (PP) method and the Internal rate of return method (IRR). The reason for using these two methods is that the PP method shows how long the project's payback period is, if the shorter the payback period for the project, the faster the capital is recovered, the less risky it is. And the IRR method specifies how much the interest rate of the project is, so that managers can make a quick and appropriate decision.

- For long-term projects with large investment capital, the appropriate method used for project analysis and evaluation is the net present value (NPV) method and the profitability index method ( PI). The reason for choosing these two methods is that the NPV method shows that the net efficiency of the project is the goal that the investor pursues while the PI method gives the investor information about the efficiency of the investment capital in the valid period of the project.

When using the methods of NPV, IRR, PI, enterprises of Vinacomin need to determine the appropriate discount rate as a basis for discounting future cash flows to the present of the projects. For investment projects with one source of capital, the discount rate is the cost of using that capital. However, at present most of Vinacomin's projects are invested with different sources of capital including loans and equity; Each source of funding varies, so the discount rate is determined as the average cost of capital for those funds.

* Complete the provision of information to make decisions on investment in fixed assets.

In order to make a decision to invest in fixed assets, the management accountants must provide sufficient information to the managers in making decisions using the reporting forms. Therefore, according to the authors, in order to meet the increasing management needs, to provide information to the managers more fully and appropriately for each type of project, the management accounting of fixed assets at enterprises of Vinacomin should improve the system of management accounting report forms as follows:

Construction management accounting Table of net present value analysis of the project, which needs detailed and specific information about the project's revenues and expenditures, eliminating value changes of monetary value over time by the discount factor to calculate the present value of the project.

\subsection{Complete collecting, processing, analyzing and providing information for the management and use of fixed} assets

In order to make the decisions regarding the management and use of fixed assets in enterprises, the fixed asset management accounting must be improved according to the following contents: 


\section{Firstly, perfect the management of fixed assets}

Currently, the number of fixed assets in enterprises of Vinacomin is very large, requiring strict management both in types and value. Although there have been many efforts in the management of fixed assets at the using departments, the ineffective use of fixed assets still occurs, assets are lost and sometimes information has not been updated timely about fixed assets. Therefore, enterprises of Vinacomin should use fixed asset management software as a solution to help enterprises synchronously manage fixed assets, manage asset records, organize the use of assets, control the operation of assets.

\section{Secondly, complete the depreciation accounting of fixed assets}

$\checkmark$ Select the appropriate depreciation policy

$\checkmark$ Determine the reasonable depreciation time of fixed assets

Thirdly, develop a system of criteria to evaluate investment efficiency and efficient use of fixed assets

Based on the operational and organizational characteristics as well as internal corporate governance requirements, the accountants at the enterprises of Vinacomin should build a system of indicators to evaluate the investment situation and technical status of the company's fixed assets in enterprises are shown below:

Table 2: The indicator system reflects the investment situation and technical status of fixed assets in the enterprises

\begin{tabular}{|c|c|c|c|}
\hline Criteria & Numerator & Denominator & Meaning \\
\hline $\begin{array}{l}\text { Return on } \\
\text { Fixed assets }\end{array}$ & $\begin{array}{c}\text { Fixed assets } \\
\text { value } \\
\text { Newly invested }\end{array}$ & $\begin{array}{l}\text { Total value of fixed } \\
\text { assets }\end{array}$ & $\begin{array}{l}\text { This reflects the level of investment in fixed } \\
\text { assets in the total asset value of the enterprise. } \\
\text { The greater the ratio, the more the business } \\
\text { focused on fixed assets. }\end{array}$ \\
\hline $\begin{array}{l}\text { Equipping factor } \\
\text { of fixed assets } \\
\text { for } 1 \text { direct } \\
\text { worker }\end{array}$ & $\begin{array}{l}\text { Historical cost } \\
\text { of fixed assets } \\
\text { directly produced }\end{array}$ & $\begin{array}{l}\text { Number of } \\
\text { workers directly in } \\
\text { production }\end{array}$ & $\begin{array}{l}\text { Reflecting the average value of fixed assets } \\
\text { provided to } 1 \text { worker in direct production. The } \\
\text { larger this number reflects the higher the level of } \\
\text { equipping the fixed assets for production of the } \\
\text { enterprise, the more favorable working } \\
\text { conditions. }\end{array}$ \\
\hline $\begin{array}{l}\text { Innovation } \\
\text { coefficient of } \\
\text { fixed assets }\end{array}$ & $\begin{array}{l}\text { The value of } \\
\text { fixed assets } \\
\text { increases in the } \\
\text { period }\end{array}$ & $\begin{array}{l}\text { Residual value of } \\
\text { fixed assets at the } \\
\text { end of the period }\end{array}$ & $\begin{array}{l}\text { In addition to reflecting pure increase or } \\
\text { decrease in scale of fixed assets, innovation } \\
\text { factors of fixed assets and elimination of fixed } \\
\text { assets also reflect the fluctuation of fixed assets; }\end{array}$ \\
\hline $\begin{array}{l}\text { Fixed asset } \\
\text { elimination } \\
\text { coefficient }\end{array}$ & $\begin{array}{l}\text { The value of } \\
\text { fixed assets } \\
\text { decreases in the } \\
\text { period }\end{array}$ & $\begin{array}{l}\text { Residual value of } \\
\text { fixed assets at the } \\
\text { end of the period }\end{array}$ & $\begin{array}{l}\text { assess the level of innovation of fixed assets of } \\
\text { enterprises. }\end{array}$ \\
\hline $\begin{array}{l}\text { Depreciation } \\
\text { coefficient of } \\
\text { fixed assets }\end{array}$ & $\begin{array}{l}\text { Accumulated } \\
\text { depreciation of } \\
\text { fixed assets }\end{array}$ & $\begin{array}{l}\text { Historical cost of } \\
\text { fixed assets }\end{array}$ & $\begin{array}{l}\text { This reflects the depreciation level of } \\
\text { fixed assets, thereby indirectly reflecting } \\
\text { the remaining capacity of fixed assets and } \\
\text { the fixed capital must continue to be } \\
\text { recovered at the time of evaluation. }\end{array}$ \\
\hline
\end{tabular}

\section{References}

Charles, T.H. \& Gary, L.S. (1993), Management Accounting,Prentice-Hall International, Inc.

Charles, T.H., George, F. \& Srikant, M.D. (1994), Cost Accounting a Managerial Emphasis, Prentice-Hall International, Inc.

Black, E. L., Sellers, K. F., Manly, T. S. (1998). "Earnings management using asset sales: an international study of countries allowing noncurrent asset revaluation." Journal of Business Finance and Accounting, 25(9), $1287-1317$.

Chua, W.F. (1986). "Radical developments in accounting thought." The Accounting Review. 61(4), 601-633.

Emanuel, D. M. (1989). "Asset revaluations and share price revisions." Journal of Business, Finance and Accounting. Spring, 213-226.

Jaggi, B. and Tsui, J. (2001). "Management motivation and market assessment: revaluations of fixed assets." Journal of International Financial Management and Accounting. 12(2), 160-187.

Lin, Y. C. and Peasnell, K. V. (2000). "Fixed asset revaluation and equity depletion in the UK." Journal of Business Finance and Accounting, 27, 359-393.

Moore, M. L. (1973). "Management changes and discretionary accounting decisions." Journal of Accounting Research. 11, 101-107.

Watts, R.L. and Zimmerman, J.L. (1978). "Towards a positive theory of the determination of accounting standards." Accounting Review, 53, 112-134. 